\title{
Do Financial Constraints Moderate the Impact of Financing Decisions From Internal-financing Sources on Investment?
}

\author{
Andewi Rokhmawati \\ Department of Management Faculty of Economics Riau University \\ Jl. HR Subrantas Km 12.5 Pekanbaru, Riau, 28293, Indonesia
}

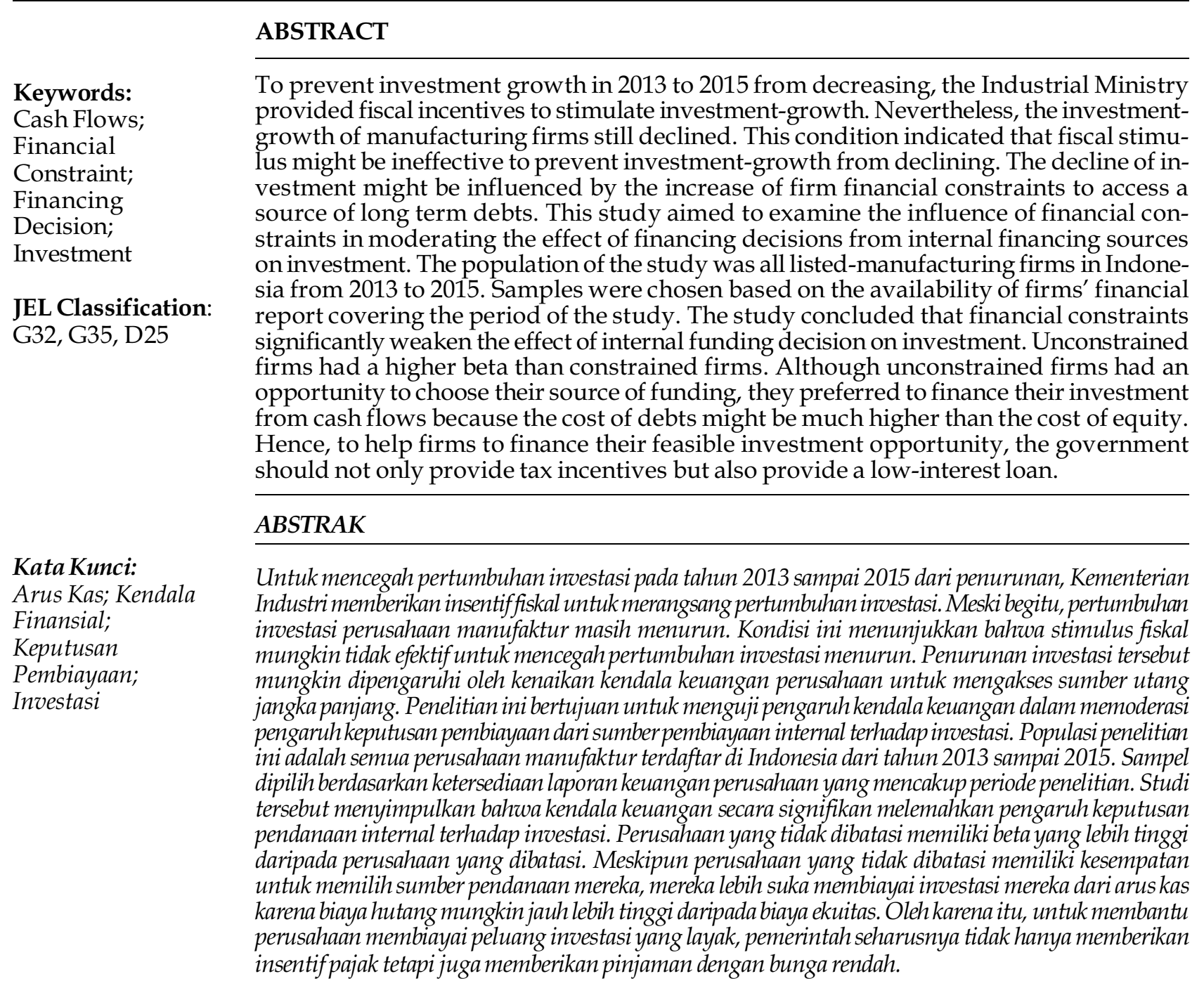

Corresponding Author:

Andewi Rokhmawati: Telp: +62 76163272

Email: andewi.rokhmawati@lecturer.unri.ac.id 


\section{Jurnal Keuangan dan Perbankan | KEUANGAN}

Vol. 21, No. 3, Juli 2017: 331-343

In 2013, Indonesia experienced a slowdown economic growth. This was because of the pressures of US economy, economic crises in Europe, and China Government policy to control its inflation (Media-Industri, 2013). The decline of economic growth affects the growth of manufacturing sectors in Indonesia. From 2012-2015, the growth of manufacturing industry experienced a decline sequentially at $6,03 \%, 5,56 \%, 5,02 \%$, and 4,79\% (Media-Industri, 2016). To prevent the industrial growth from declining, the Indonesian Industrial Ministry provided fiscal incentives to stimulate investment growth (Media-Industri, 2013). Table 1 is showing the selected financial condition of Indonesian listed manufacturing firms.

The growths of selected financial indicators in Table 2 can be graphed as Figure 1.

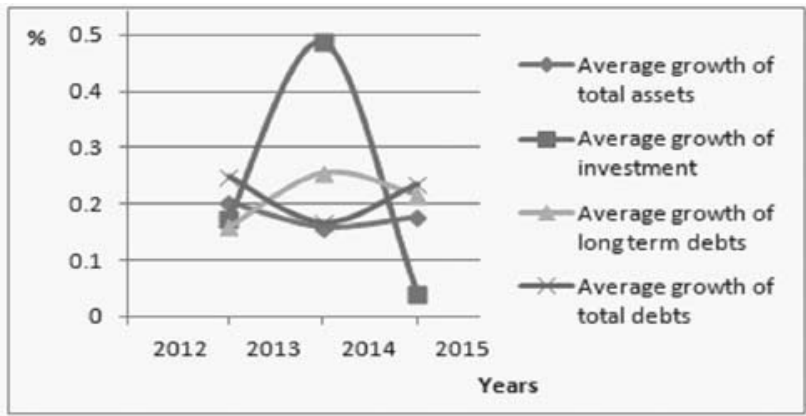

Figure 1. Growths of selected Financial Indicators from Listed Manufacturing Firms in IDX from 2012-2015
Figure 1 shows that nominally from 20122015 , the average of total assets, average investment, long term debts, and short term debts increased gradually but when the data were seen as a growth the average growth of investment, and long term debts in mid-2012 to mid-2013 increased but in mid-2014 to mid-2015 experienced a decrease. This condition is in contrast with average growth of total debts and total assets that decreased in mid-2012 to mid-2013 but increased slightly in mid-2014 to mid-2015. The increase in the growth of average total assets was followed with a significant decrease in investment growth on fixed assets. This condition indicates that fiscalstimulus from the government might be effective enough to increase the growth of total assets but not effective to increase investment in fixed assets. The decline of investment in fixed assets might be affected by the increase of firm financial constraints to access a source of external funding such as long term debts. This phenomenon is interesting to be investigated. This research, therefore, aims to examine the influence of financial constraints in moderating the effect of financing decisions from internal financing sources on investment.

Investment is important as maximizing the firm's value can only be realized through the firm's

Table 1. Selected Financial Indicators from Listed Manufacturing Firms in IDX (2012 - 2015)

\begin{tabular}{lrrrr}
\hline & \multicolumn{1}{c}{$\mathbf{2 0 1 2}$} & \multicolumn{1}{c}{$\mathbf{2 0 1 3}$} & \multicolumn{1}{c}{$\mathbf{2 0 1 4}$} & $\mathbf{2 0 1 5}$ \\
\hline Average Total Assets & $3,864,475,577,291$ & $4,653,988,198,679$ & $5,391,278,599,483$ & $6,345,002,795,204$ \\
Average Investment & $215,641,889,877$ & $253,329,627,624$ & $376,854,854,000$ & $392,934,848,922$ \\
Average Long Term Debts & $573,213,959,661$ & $664,779,060,627$ & $835,101,394,235$ & $1,016,888,023,039$ \\
Average Short Term Debts & $1,545,823,873,356$ & $1,931,947,325,166$ & $2,253,809,287,731$ & $2,785,812,122,057$ \\
\hline
\end{tabular}

Source: Calculated Based on Data from Individual Manufacturing Firm Listed in IDX

Table 2. Growths of Selected Financial Indicators from Listed Manufacturing Firms in IDX (2012 - 2015)

\begin{tabular}{lccc}
\hline & $\mathbf{2 0 1 2 - 2 0 1 3}$ & $\mathbf{2 0 1 3 - 2 0 1 4}$ & $\mathbf{2 0 1 4 - 2 0 1 5}$ \\
\hline Average growth of total assets & $20.4 \%$ & $15.8 \%$ & $17.7 \%$ \\
Average growth of investment & $17.5 \%$ & $48.8 \%$ & $4.3 \%$ \\
Average growth of long term debts & $16.0 \%$ & $25.6 \%$ & $21.8 \%$ \\
Average growth of total debts & $25.0 \%$ & $16.7 \%$ & $23.6 \%$ \\
\hline
\end{tabular}

Source: Calculated Based on Data from Individual Manufacturing Firm Listed In IDX 
investment activities. The amount of investment tightly correlates with financing decision because financing decision has implication on the cost of capital (Khan \& Adom, 2015). Financing decisions involve from where the source of funds to finance the investments. Source of firm funding can be sourced from internal and external sources. Internal sources can be from the cash flows generated from firm operation. External sources can be got from debts. Furthermore, the firm capability to get loans depends on firm condition. Firms with financial constraints may get difficulties to acquire an external source of funding (Fazzari et al., 1988).

Many studies such as Fazzari et al. (1988), Vogt (1994), Kaplan \& Zingales (1997), Cleary (1999), and Moyen (2004) have been conducted to examine the relationship between financing decision and investment. To do so, they classified firms into 2 groups namely financially constrained firms and financially unconstrained firms. By measuring financial constraints as a dummy variable, they compared the effect of cash flows on investment between unconstrained firms and constrained firms. Level of cash flows represents financing decision that the financing is from the internal firm. There are 2 reversal results of empirical tests of the relationship between cash flows of unconstrained firms and constrained firms on investment that will be discussed further.

The first group of research provided the result that constrained firms have a higher beta than unconstrained firms (Vogt, 1994; Hermeindito, 2004). Based on asymmetric information theory, Fazzari et al. (1988) developed logical thinking to link between cash flows and investment. Asymmetric information occurs because information about firm condition owned by management and information held by the creditors is unequal (Ehrhardt \& Brigham, 2014). The management comprehends firm's condition and prospects in detail and complete. Meanwhile, creditors have limited information about firm's condition and prospects. This asymmetry makes external fund- ing becomes very costly because the creditors can have difficulties to assess the quality of firm's investment opportunities and risks. As a result, the creditors will require a cost of debt which is much higher than the cost of funds from its internal source (Lemmon \& Zender, 2016). The higher the degree of information asymmetry, the greater the constraints of firms to access external funding. Accordingly, the firm will much rely on the availability of cash flows generated from firm operating activities. Fazzari et al. (1988) explained that firms that are facing financial constraints when their external source of funding becomes very expensive, so the firms can only use their internal source of funds to finance investment. Consequently, to provide enough cash for their investment, the firms will tend to apply a small dividend payout ratio. This means that the firms will increase the portion of retained earnings. Fazzari et al. (1988) identified firms with lower dividend classified as more constrained and firms with higher dividend classified as lesser constrained. Accordingly, in terms of the internal source of financing decision, firms with financial constraints will have higher beta than firms without financial constraints. It means that constrained firms depend more on the availability of cash flows (internal funds) than unconstrained firms.

There are some weaknesses of the study of Fazzari et al. (1988). Firstly, the literature indicates that shorting the beta (sensitivity of cash flowsinvestment) based on the classification of the level of financial constraints faced by firms greatly depends on how the researchers measure the concept of financial constraints. Hence, classifying firms into financially constrained and non-financially constrained based on a priori, where the classification is used to develop an interpretation on the sensitivity of cash flows-investment may be questionable for the validity. Secondly, the measurement of investment using Tobin's q is indicated to contain a measurement bias since Tobin's $\mathrm{q}$ does not consider investment in fixed assets that 


\section{Jurnal Keuangan dan Perbankan | KEUANGAN}

Vol. 21, No. 3, Juli 2017: 331-343

need cash flow availability. Hence fixed assets are considered more reliable to the measurement of investment. Furthermore, cash flows are able to capture the phenomenon of financial constraints. When firms face financial constraint, they will much rely on the internal source of funds. Conversely, firms without financial constraint may less rely on the internal source of funds. They have a flexibility to their source of funds since they have access to external funds. Accordingly, the capability of firms to provide funds (whether from internal or external) will affect their investment. This reasoning provides a clear explanation of the relationship between financing decision from internal sources, financial constraints, and investment. Thirdly, there are potential problems about misspecification of Fazzari's model. Debt is considered to be an important variable since this variable has a significant correlation to the availability of cash flows but Fazzari et al. (1988) do not include debts in the model. Firms that have debts must pay monthly installment. The installment would reduce the availability of firm's cash. The second group such as Kaplan \& Zingales (1997), Cleary (1999), Baker et al. (2003), and Hermeindito (2004), provided a contradicted result. Kaplan \& Zingales $(1997,2000)$ used qualitative data available through interviewing firm managers and quantitative data available in financial statements of firms to classify firms into a group of developed financial constraints. Kaplan \& Zingales $(1997,2000)$ found that unconstrained firms have a higher beta than constrained firms. It means that firms with easier access to external funds have relied more on internal funds (cash flows) than external funds. Kaplan \& Zingales (1997) argued that managers of unconstrained firms may avoid risk in deciding their investment.

Based on the explanation above, it can be concluded that many studies have examined the relationship between cash flows, financial constraints, and investment but the results have been mixed. This research adopts Kaplan \& Zingales' and Fazzari's model but has dissimilarities with their measurements on classifying financially constrained and unconstrained firms. This research does not use the qualitative and quantitative approach as it is used by Kaplan \& Zingales (1997) but uses a quantitative approach with a probit model. Probit model in this research will be discussed in the methods section. Furthermore, this research does not use Tobin's q as the proxy of investment as it is used by Fazzari et al. (1988) but uses fixed assets i.e. plant, property, and equipment (PPE). This research includes leverage to capture debt usage as a control variable to address the weakness of Fazzari's model. This research also includes firm size and sales as control variables to improve the goodness of fit of the researchmodel. However, this research does not include cash holding due to the expected multicollinearity problem with cash flows. The contribution of this study, therefore, will be on the improvement model of Fazzari and the use of probit model to assign a firm whether it is classified as financially constrained or unconstrained that it is different from Kaplan \& Zingales' Model.

\section{HYPOTHESES DEVELOPMENT}

Asymmetric information as stated above provided us reasoning how financing decision from internal sources affects investment. Asymmetric information makes external funds becomes very costly because the creditors have difficulties to evaluate and assess the quality of firm's investment opportunities and risks. As a result, the creditors will require a cost of debt which is much higher than the cost of funds from its internal source (Lemmon \& Zender, 2016). Accordingly, the constrained firms will much rely on the availability of cash flows. Furthermore, pecking order theory (Myers \& Majluf, 1984) sorts the source of funds from the cheapest to the most expensive. Sequentially, they have retained earnings, bank loans, issuing bonds, preferred stocks, and common stocks. Firms will use retained earnings (in- 
ternal source of funding) first to finance their investment if the source of internal funds is not enough, firms can get the shortage from external sources i.e. bank loans, then issuing bonds, and so on. Deciding to finance investment from bank loans must consider that the investment rate of return must be higher than the cost of debts. Kaplan \& Zingales (1997) said that financial constraints could occur if the firm faces a significant difference between the cost of capital from internal funds and the cost of capital from external funds. This definition provides a useful framework to distinguish firms into financially constrained and financially unconstrained. Firms with financial constraints are characterized by a difficulty to obtain funds from external sources (Kaplan \& Zingales, 1997). Hence, the limitation will eventually impede firms' ability to invest, so constrained firms will highly depend on cash flows (internal funds). Conversely, unconstrained firms have a flexibility to their source of funding so they have access external funding. Eventually, they less depend on internal funds (cash flows). This can be concluded that constrained firms will have a higher beta (cash flow sensitivity on investment) than unconstrained firms. In other words, the financial constraint will strengthen the effect of cash flows on investment. Based on this explanation, some hypotheses can be proposed as follows:

$\mathrm{H}_{1}$ : internal source of financing (cash flows) of unconstrained firms have a positive and significant effect on investment. The beta is expected to be higher than constrained firms' beta.

$\mathrm{H}_{2}$ : financial constraints strengthen the effect of internal source of financing (cash flows) on investment.

\section{METHODS}

The population of this research is all listed manufacturing firms listed on the Indonesian Stock Exchange (IDX). They are 137 manufacturing firms listed in 2013-2015 so there are 411 cases. Samples are selected based on purposive sampling based on the availability of financial reports covering from 2013-2015. From 137 firms, there are 108 firms provided financial reports covering that period. Hence, there are 324 cases covered in this research. All data in this study will be obtained from Indonesian Capital Market Directory.

\section{Investments}

Generally, investments in fixed assets will be received back within more than one year and will be accepted gradually (Hidayat, 2010). In this research, investment is measured as cash invested in PPE subtracted with cash received from selling PPE (Chang et al., 2009). This research divides investment with the book value of total assets to address the issue of heterogeneity of firms' size. Firm A and Firm B. Firm A has investment IDR10,000,000 and total assets IDR1,000,000,000. Firm B has investment IDR1,000,000 and total assets IDR10,000,000. Nominally, Firm A has higher investment than Firm $B$ but relatively from its total assets Firm A has investment 1\% and Firm B has $10 \%$ investment.

Investment $_{\mathrm{t}}=\frac{(\text { Cash invested in PPE }- \text { Cash received from selling PPE })_{\mathrm{i}, \mathrm{t}}}{\text { Book value of total assets } \mathrm{i}_{\mathrm{i}, \mathrm{t}-1}} \ldots(1)$

Where,

PPE : plant, property and equipment.

$t \quad:$ the book value at the end of the year $t$

$t-1$ : the book value at the beginning of year $t$

\section{Cash Flows as Internal Source of Funding}

Firms that lack access to an external source of funding will greatly depend on the availability of internal funds (cash flows generated from firm operating activities) to finance the firm investment. Cash flows are measured with following formula (Kaplan \& Zingales, 1997). This research uses total 


\section{Jurnal Keuangan dan Perbankan | KEUANGAN}

Vol. 21, No. 3, Juli 2017: 331-343

assets as denominator to avoid heterogeneity of firms' size:

Cash flows $_{\mathrm{i}, \mathrm{t}}=\frac{[\text { Net in come }+ \text { Depreciation and amortization }]_{\mathrm{i}, \mathrm{t}}}{\text { Book value of total assets } \mathrm{i}, \mathrm{t}-1} \ldots$

\section{Financial Constraints}

This study uses a logit model to get predictive classification based on the consideration that the logit model is more lenient from normal distribution assumption (Eisenbeis, 1977). This research uses dividend payment as the proxy of financial constraints as Deng et al. (2017) used. However, different from Deng's, this research threatens dividend payment as a dummy variable. Firms are classified as financially constrained if the firms do not pay a dividend. Such firms are assigned score one; otherwise zero. Financial constraint is a function of these following variables: (1) liquidity is measured with current ratio. Firms with high liquidity may be able to pay dividend; (2) profitability reflects the availability of financial resources to generate cash flows; (3) change in profit is measured as a dummy variable, which is a score of zero is assigned for negative change and one is for positive change; (4) retained earnings reflect the availability of internal funds; and (5) slack reflects the availability of funds that can be used to finance investment.

These following steps are the steps to measure financial constraints: (1) to make a logit model to predict financial constraints with following equations.

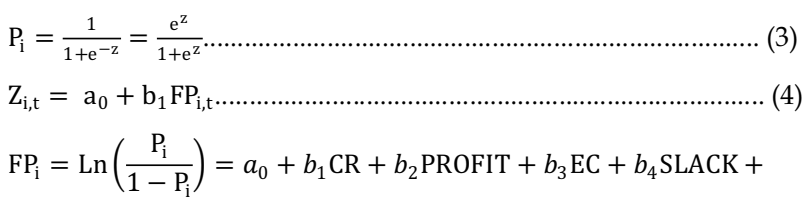

$b_{5} R E+\varepsilon_{i, t}$

Where:

$\mathrm{FP}_{\mathrm{i}} \quad$ : Financial constraints of firm $\mathrm{i}$

CR (Current Ratio) : : current assets / sort term debt.

\begin{tabular}{|c|c|}
\hline \multirow{3}{*}{$\begin{array}{l}\text { PROFIT } \\
\text { EC (EAT Change) }\end{array}$} & Operating Income / Total Assets.. (7) \\
\hline & Positive Changes: 1 , \\
\hline & Negatives changes: 0 \\
\hline \multirow[t]{3}{*}{ SLACK } & [Cash + Short Term Investment \\
\hline & + Inventories + Receivables - \\
\hline & Current Debt]/Total Assets........ (8) \\
\hline RE (retained earnings) & Retained earnings / Total Assets. (9) \\
\hline$P_{i}$ & Probability \\
\hline 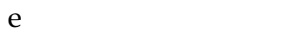 & exponential value \\
\hline
\end{tabular}

(2) to calculate the probability $\left[\operatorname{Ln}\left(\mathrm{P}_{\mathrm{i}} / 1-\mathrm{P}_{\mathrm{i}}\right)\right]$ noted as $\mathrm{FP}_{\mathrm{i}}$ in equation 5 based on the estimation results of $a_{0^{\prime}}, b_{1^{\prime}}, b_{2^{\prime}}, b_{3^{\prime}}, b_{4^{\prime}}$ and $b_{5}$ of the logit model. The probability is used to determine the cut-off $\left(C^{*}\right)$ as an objective criterion for distinguishing firms based on financial constraints. If the firm's $\mathrm{FP}_{\mathrm{i}}$ is greater than the cut off $\left(\mathrm{FP}_{\mathrm{i}}>\mathrm{C}^{*}\right)$, the firm is categorized as constrained firm. Conversely, if $\mathrm{FP}_{\mathrm{i}}<\mathrm{C}^{*}$, the firm is categorized as unconstrained firm; and (3) to determine the cut-off value $\left(\mathrm{C}^{*}\right)$ that is based on the percentile value of 67.78 percent. Firms that have $\mathrm{FP}_{\mathrm{i}}$ greater than $\mathrm{C}^{*}(67.78$ percent percentile values) are grouped as financially constrained. In contrast, firms that have $\mathrm{FP}_{\mathrm{i}}$ lower than $C^{*}$ (67.78 percent percentile values) are grouped as financially unconstrained.

\section{Control Variables}

Some of control variables that may have an effect on investment decisions included in the study that can be seen as follows:

Leverage measured by the following formula (Aivazian et al., 2005):

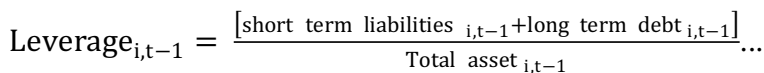

Size is measured with Size $_{i, t}$

$=\operatorname{Ln}\left(\right.$ total aset $\left._{\mathrm{i}, \mathrm{t}}\right)$ (Chang et al., 2009).

Sales are measured in Ln sales ${ }_{t}$ (Chang et al., 2009)...

A research model for the relationship between financial constraints and the sensitivity of cash flows-investment can be developed as follows: 
Investment $_{\text {it }}=\alpha_{1}+\beta_{1} \mathrm{CF}_{\mathrm{it}}+\beta_{2} \mathrm{FC}_{\mathrm{it}}+\beta_{3} \mathrm{CF}_{\mathrm{it}} * \mathrm{FC}_{\mathrm{it}}+$
$\beta_{4}$ Size $_{\mathrm{it}}+\beta_{5}$ Leverage $_{\mathrm{i}, \mathrm{t}-1}+\beta_{6}$ Sales $_{\mathrm{it}-1}+\varepsilon_{\mathrm{it}} \ldots \ldots \ldots$

Where:

Investment : capital expenditures measured as total asset at beginning of year

CF : cash flows

FC : financial constraints measured as dummy variable taken the value one for financially constrained and zero for otherwise.

$\beta_{0} \quad$ : constant variables

$\beta_{1^{\prime}}, \beta_{2^{\prime}}, \beta_{3^{\prime}}, \beta_{4^{\prime}}, \beta_{5^{\prime}}, \beta_{6}$ : regression coefficient

$\mathrm{t}-1 \quad$ : the beginning of the period

$\mathrm{i} \quad: 1,2, \ldots, \mathrm{n}$ is the number of units/ individual cross section

$\mathrm{t} \quad: 1,2, \ldots, \mathrm{t}$, is the number of time periods

$\varepsilon \quad$ : error

Statistical results of equation (12) can be interpreted as follows: (1) $\beta_{1}$ measures the sensitivity of the effect of cash flows on investment for unconstrained firms; (2) $\beta_{2}$ measures the sensitivity of the effect of financial constraints on investment, where financial constraints as an independent variable; (3) $\beta_{3}$ measures the sensitivity dif- ference of the effect of cash flows on investment between unconstrained and constrained firms; and (4) constrained firms denoted with $\beta_{\text {total }}$ are measured with $\beta_{1}+\beta_{3}$.

\section{Classic Assumption Tests}

Before conducting a regression analysis, the developed model is tested from the classical assumptions. Classic assumption tests consist of normality test of the residual of the regression, multicollinearity, heteroscedasticity, and autocorrelation (Ghozali, 2011). Although this model uses three-year observations, this research does not conduct autocorrelation test since the research model does not treat the data as panel data involving time series and cross sectional data but as repeated cross sectional data.

\section{RESULTS}

After the regression model passed from the normality, multicollinearity, and heteroscedasticity test (the result of the series tests can be seen in Appendix 1), the regression result can be seen as follows.

\section{Descriptive Statistics}

The descriptive statistics can be seen in Table 3 . Because residuals of the regression are not normal, this research transformed investment into

Table 3. Descriptive Statistics

\begin{tabular}{lrrrrr}
\hline & \multicolumn{3}{c}{ Descriptive Statistics } & Mean & Std. Deviation \\
\hline SQRTinvestment & $\mathrm{N}$ & \multicolumn{1}{c}{ Minimum } & Maximum & 14.694240 & 1.1802323 \\
CF & 323 & 12.5240 & 20.0912 & 8.435638 & 4.6517073 \\
CF_FC & 324 & .1136 & 22.1059 & 1.304194 & 3.1894950 \\
LnSize & 324 & .0000 & 13.3476 & 789.745382 & 49.0813763 \\
Leverage & 324 & 682.1461 & 915.5867 & 8.898240 & 4.4021946 \\
LnSales & 324 & .2840 & 21.0153 & 784.800701 & 61.4546261 \\
\hline Constrained Firms & 324 & 560.0869 & 932.2569 & &
\end{tabular}




\section{Jurnal Keuangan dan Perbankan | KEUANGAN}

Vol. 21, No. 3, Juli 2017: 331-343

square root (SQRT) form and transformed size and sales into logarithm natural (Ln) form. Furthermore, outlier data also were removed from the analysis to get a normal distribution. There is one data that is removed from the analysis because of an outlier. This table does not have mean and Std. Deviation for constrained firms because of a dummy variable. The number of constrained firms is 63 firms so that the number of unconstrained firms is 260 . The table shows that the average investment in SQRT form is 14.694240 and the average of cash flows is 8.435638 .

\section{Coefficient Determination $\left(\mathbf{R}^{2}\right)$}

Coefficient determination shows the goodness of fit of model. Table 4 shows that $\mathrm{R}^{2}$ is equal to 29.7 percent. It means that independent variables included in the model can explain investment at 29.7 percent. The rest (70.3 percent) is explained by other variables excluded from the model.

\section{Simultaneous Effect Test (F Test)}

F test also shows the goodness of fit of the model. The fitness of the model can be seen from the significance level (alpha).

Table 4. Coefficient Determination $\left(R^{2}\right)$

\begin{tabular}{llllr}
\hline & & \multicolumn{2}{c}{ Model Summary } & \\
\cline { 3 - 4 } Model & $\mathrm{R}$ & R Square & Adjusted R Square & Std. Error of the Estimate \\
\hline 1 & $.545^{\mathrm{a}}$ & .297 & .284 & .9985729 \\
\hline $\begin{array}{l}\text { a. Predictors: (Constant), LnSales, FC, CF, LnSize, Leverage, CF_FC } \\
\text { b. Dependent Variable: SQRTinvestment }\end{array}$
\end{tabular}

Table 5. Result of F Test

\begin{tabular}{rlcrrrr}
\hline \multicolumn{7}{c}{ ANOVA $^{\mathbf{a}}$} \\
\hline Model & & Sum of Squares & df & Mean Square & F & Sig. \\
\hline \multirow{2}{*}{1} & Regression & 133.431 & 6 & 22.238 & 22.302 & $.000^{\mathrm{b}}$ \\
& Residual & 315.099 & 316 & .997 & \\
& Total & 448.529 & 322 & & & \\
\hline
\end{tabular}

a. Dependent Variable: SQRTinvestment

b. Predictors: (Constant), LnSales, FC, CF, LnSize, Leverage, CF_FC

Table 6. Result of t Tests

\begin{tabular}{|c|c|c|c|c|c|c|c|c|}
\hline \multirow{3}{*}{\multicolumn{2}{|c|}{ Model }} & \multicolumn{3}{|c|}{ Coefficients $^{a}$} & \multirow{3}{*}{$\mathbf{t}$} & \multirow{3}{*}{ Sig. } & \multirow{2}{*}{\multicolumn{2}{|c|}{ Collinearity Statistics }} \\
\hline & & \multicolumn{2}{|c|}{$\begin{array}{l}\text { Unstandardized } \\
\text { Coefficients }\end{array}$} & \multirow{2}{*}{$\begin{array}{c}\text { Standardized } \\
\text { Coefficients } \\
\text { Beta }\end{array}$} & & & & \\
\hline & & B & Std. Error & & & & Tolerance & VIF \\
\hline & (Constant) & 9.413 & .999 & & 9.423 & .000 & & \\
\hline & CF & .062 & .014 & .246 & 4.300 & .000 & .682 & 1.466 \\
\hline & $\mathrm{FC}$ & .157 & .295 & .053 & .533 & .594 & .229 & 4.376 \\
\hline 1 & CF_FC & -.073 & .035 & -.199 & -2.099 & .037 & .249 & 4.022 \\
\hline & LnSize & .004 & .001 & .147 & 2.493 & .013 & .642 & 1.557 \\
\hline & Leverage & -.045 & .018 & -.167 & -2.488 & .013 & .496 & 2.016 \\
\hline & LnSales & .003 & .001 & .161 & 2.764 & .006 & .654 & 1.530 \\
\hline
\end{tabular}

a. Dependent Variable: SQRT investment 
Table 5 shows that the value of alpha is less than 0.05 . It means that simultaneously independent variables, i.e. LnSales, Leverage, $\mathrm{CF}$, LnSize, CF_FC, and FC significantly affect investment.

\section{The Result of $t$ Tests}

$\mathrm{T}$ tests provide the decision of whether proposed hypotheses are accepted or rejected. The result of $t$ tests can be seen in Table 6 .

Based on the result in Table 6, the research model can be formulated as follows:

$$
\begin{aligned}
& \text { SQRTInvestment }_{\mathrm{it}}=9.413+0.062 \mathrm{CF}_{i t}+0.157 \mathrm{FC}_{\mathrm{it}} \\
& -0.073 \mathrm{CF}_{i t} * \mathrm{FC}_{\mathrm{it}}+0.004 \mathrm{LnSize}_{\mathrm{it}}-0.045 \text { Leverage }_{\mathrm{i}, \mathrm{t}-1} \\
& +0.003 \mathrm{LnSales}_{\mathrm{it}-1}+\varepsilon_{i t} \ldots \ldots \ldots \ldots \ldots \ldots \ldots \ldots \ldots \ldots \ldots \ldots \ldots \ldots \ldots \ldots \ldots \ldots \ldots \ldots \ldots \ldots \ldots \ldots
\end{aligned}
$$

The model can be read as follows: (1) when all independent variables are zero, the SQRTinvestment will be 9.413 ; (2) $\beta_{1}$ is 0.062 . This is the beta for unconstrained firms. The beta 0.062 indicates that the increase in cash flows by 1 percent will affect the increase in the SQRTinvestment by 0.062 percent if other independent variables except cash flows are zero. The effect is also significant since the alpha is less than 0.05 ; (3) $\beta_{2}$ is 0.157 implying that if other independent variables are zero the increase of financial constraints by 1 percent, the SQRTinvestment will increase by 0.157 percent. The effect is not significant; (4) $\beta_{3}$ is -0.073 measuresthe sensitivity difference of the effect of cash flow on investment between unconstrained and constrained firms. The effect is significant. It means that financial constraints significantly weaken the effect of cash flows on investment; (5) beta $(\beta)$ for constrained firms is -0.011 measured from $0.062+(-0.073)$. Beta -0.011 means that the increase of cash flows by 1 percent, the SQRTinvestment will decrease by 0.011 percent if other independent variables except cash flows are zero; (6) $\beta_{4}$ for Ln size is significant the direction is as expected. The increase in Size will increase in
Investment; (7) $\beta_{5}$ for leverage is significant and the direction is not as expected. The increase in leverage will reduce investment; and (8) $\beta_{6}$ for Lnsales is significant and the direction is as expected. The increase in sales will increase investment. Sales will produce cash and the cash will be used to finance firm investment.

\section{DISCUSSION}

The result in Table 6 provides empirical evidence that cash flows (internal source of funds) have a positive and significant effect on investment but the beta of unconstrained firms (0.062) is significantly higher than the beta of constrained firms (-0.011). The result is consistent with the findings documented by Kaplan \& Zingales (1997) and Cleary (1999) that unconstrained firms have a more sensitive cash flows-investment than constrained firms. The statistic result implies that although unconstrained firms may have access to an external source of funding, they prefer to use cash flows generating from the firm operation rather than use an external source of funding. This may because unconstrained firms are able to earn a large amount of cash from their operation, so they have the capability to finance their investment from cash flows. Although unconstrained firms have access to external funds, they appear to prefer not to use external funds because the utilization of external funds will increase risk. They realized that the slowdown economic growth increases business risks for them so that they try to reduce the usage of long term debts to avoid the worsening of risks. The increase in debt level will worsen the availability of cash flows since firms must pay higher interest that eventually firm investment will decrease. This is strengthened by the significant negative effect of leverage on investment included in this research. Unconstrained firms have a flexibility to choose their source of funding. The result of this research supports the result of ArslanAyaydin et al. (2014) that flexibility to choose the 


\section{Jurnal Keuangan dan Perbankan | KEUANGAN}

Vol. 21, No. 3, Juli 2017: 331-343

source of funding is a significant factor to affect investment, especially during economic crises.

$\beta_{3}$ has a negative sign meaning that financial constraints weaken the effect of cash flows on investment. The result does not confirm the hypothesis that financial constraints should strengthen the effect of internal source of financing decision on investment. Firms with financial constraint should have a higher beta than unconstrained firms. A higher beta reflects that constrained firms more rely on cash flows generating from firm operating activities. Hence, the increase in financial constraint should be followed by the increase in the usage of cash flows to finance their investments. The effect should be positive and significant. In contrast with the proposed hypothesis, this research provides that cash flows have a negative and significant effect on investment. This fact is interesting that can be explained as follows. The decrease of economic growth may pressure firms' operation so that it may worsen the ability of financially constrained firms to generate cash flows. As a result, their investment on fixed assets (PPE) declined significantly. This may be the indication that constrained firms, where they do not have access to an external source of funding, the increase in cash flows may not be used to finance their investment but the cash flows may be used to support their working capital so that their investment experienced a decline. This is in line with Figure 1 showing that from mid-2013 to mid-2015 there was a decline in investment growth in PPE but there was an increase in the total asset.

Additionally, financial constraints significantly weaken the effect of cash flows on investment. Constrained firms have a lower beta than unconstrained firms. It implies that constrained firms lack access to an external source of funding, so they solely rely on internal cash flows. The decrease in economic growth may make constrained firms more difficult to generate money from their operation, so constrained firms tend to under invest (Dogru \& Sirakaya-Turk, 2017). They lack cash flows, so they tend to not finance their investment opportunities with positive net present value (NPV). Financing the profitable investment opportunities by using debts make the opportunities become no longer feasible (negative NPV) due to the very expensive cost of debts. The result of the statistic has negative sign meaning that the increase in cash flows of constrained firms will reduce their investment. It is in line with the preference of constrained firms to let investment opportunities go because they do not have enough cash flows to finance their investment. Furthermore, the financial constraint may also be defined as not only limited access to external funding but also limited ability to generate money from their operational activities.

The research finding implies that the fiscal incentives might be not effective enough to prevent firm investment from declining. There is several reasoning to justify this claim. Firstly, Regulation of the Minister of Industry No. 41 of 2013 was based on the Minister of Finance Regulation Number 124 of 2013 on Redemption Amount of Income Tax Article 25 and Procrastination Income Tax Article 29 of 2013 for compulsory specific industry tax. Regulation of the Minister of Industry No. 41 of 2013 classified manufacturing firms that are eligible to get fiscal incentives. The eligible firms are classified as labor-intensive industries, and micro, small, and medium-scale industries (Media-Industri, 2013). Hence, not all types of industries get fiscal incentives. This may be the reason why this regulation was not effective enough to prevent investment growth of manufacturing industry from declining. Secondly, a tax-incentive regulation will work effectively if it is able to reduce the cost of capital (International-MonetaryFund, 2015a). International Monetary Fund (2015b) suggested that there are several tax incentives that are effective to reduce the cost of capital, such as accelerated depreciation schemes, investment tax credits, and super deductions. In contrast, openended and profit-based tax holidays are less ef- 
fective because of the benefit of incentives less than the capital cost of investment. Thirdly, Bank Indonesia (Jacobs, 2014) decided to keep the BI Rate at 7.50 percent made manufacturing firms difficult to keep their investment growth sustained.

From Table 2 that although in 2012-2015 nominally firms' investment increases but the growth in investment actually declined significantly. Hence, the tax-incentive regulation to prevent firm investment growth from declining may not suitable because the problem may be at the very expensive cost of capital. Accordingly, providing soft loans for firms may be a more suitable policy in the condition of declining national economic growth.

\section{CONCLUSION AND SUGGESTIONS}

\section{Conclusion}

From the value of beta and significance value of the statistic results, the study concluded that firstly, cash flows of unconstrained firms have a significant effect on investment. Secondly, financial constraints significantly weaken the effect of cash flows on investment. It means that unconstrained firms may prefer not to use external funds to finance their investment due to the expensive cost of capital. Constrained firms have seen having limited ability to generate money from their operation so that they have a lesser beta. Constrained firms tend to under invest.

\section{Suggestions}

The results of this research have several recommendations for policy, practice, theory, and future research. For policy, the financial incentive provided by the government to stimulate investment growth appears not effective since the growth of investment remains declines significantly. The availability of soft loans may help firms to reduce their installment so that they will get a flexibility to use their cash flows. Then, the availability of cash flows will increase investment.

For practice, when firms are under the slowdown economic growth, to decrease firm risks it is recommended that unconstrained firms with strong cash flows should use their internal cash flows to finance their investment rather than using debts. This recommendation has implication for firms that firms can apply less dividend payout ratio.

This research has a recommendation for theory. It is known that pecking order theory shorts the source of funding from the cheapest to the most expensive. The theory is applicable for Indonesia particularly in decreasing economic growth where uncertainties increase so risks also increase that accordingly cost of capital from external sources increases as well. Hence, unconstrained firms prefer to use cash flows rather than debts to finance their investment. This has an implication that firms may distribute a dividend in a small amount so that the firms retain a large amount of profit to finance firm investment opportunities rather than they have to get loans. This is because the cost of debts is higher than the cost of equity.

Finally, the results of this study also have implication for future studies. This study does not include dividend payout ratio (DPR) as an independent variable in the model. This variable may have an explanation to support the hypothesis if firms prefer to use cash flows so that firms will reduce their DPR. Future research may also include economic growth into the model to capture the explanation which one either economic growth or financial constraint dominantly affects investment. Finally, future studies may include the data in 2016 as well since there are many new regulations introduced by the new government to support a better system to increase investment growth. 


\section{Jurnal Keuangan dan Perbankan | KEUANGAN}

Vol. 21, No. 3, Juli 2017: 331-343

\section{REFERENCES}

Arslan-Ayaydin, Ö., Florackis, C., \& Ozkan, A. 2014. Financial Flexibility, Corporate Investment and Performance: Evidence from Financial Crises. Review of Quantitative Finance and Accounting, 42(2): 211250.

Aivazian, V.A., Ge, Y., \& Qiu, J. 2005. The Impact of Leverage on Firm Investment: Canadian Evidence. Journal of Corporate Finance, 11(1-2): 277-291.

Baker, M., Stein, J.C., \& Wurgler, J. 2003. When Does the Market Matter? Stock prices and the Investment of Equity-Dependent Firms. Quarterly Journal of Economics, 118: 969-1004.

Chang, X., Faff, R., Kwok, W.C., \& Wong, G. 2009. Financial Constraints, Mispricing, and Corporate Investment. http://ssrn.com/abstract=1101361. Retrieved May 4, 2016.

Cleary, S. 1999. The Relationship between Firm Investment and Financial Status. The Journal of Finance, 54(2): 673-692.

Deng, K., Ding, Z., Zhu, Y., \& Zhou, Q. 2017. InvestmentCash Flow Sensitivity Measures Investment Thirst, but Not Financial Constraint. Accounting E Finance Journal, 57(1): 165-197.

Dogru, T. \& Sirakaya-Turk, E. 2017. The Value of Cash Holdings in Hotel Firms. International Journal of Hospitality Management, 65: 20-28.

Ehrhardt, M.C. \& Brigham, E.F. 2014. Corporate Finance: A Focused Approach. $6^{\text {th }}$ Edition. Ohio: Cengage Learning.

Eisenbeis, R.A. 1977. Pitfalls in the Application of Discriminant Analysis in Business, Finance, and Economics. The Journal of Finance, 32(3): 875-900.

Fazzari, S.M., Hubbard, R.G., \& Petersen, B.C. 1988. Financing Constraints and Corporate Investment. Brookings Paper on Economic Activity, 1988(1): 141206.

Ghozali, I. 2011. Aplikasi Analisis Multivariate dengan Program SPSS 19. Semarang: Badan Penerbit Universitas Diponegoro.

Hermeindito. 2004. Information Asymmetry and Management Control: Sensitivity Analysis of Invest- ment and Leverage Funding Sources Selection. Dissertation. Gadjah Mada University Yogyakarta.

Hermeindito. 2004. Informasi Asimetri dan Kontrol Manajemen: Analisis Kepekaan Investasi dan Leverage terhadap Pemilihan Sumber-Sumber Pendanaan. Dissertation. Gadjah Mada University Yogyakarta.

Hidayat, R. 2010. Keputusan Investasi dan Financial Constraint: Study Empiris Pada Bursa Efek Indonesia. Buletin Ekonomi Moneter dan Perbankang, 12(4): 458-479.

International-Monetary-Fund. (2015a). Making Public Investment More Efficient. Washington: International Monetary Fund.

International-Monetary-Fund. (2015b). World Bank, OECD, UN, Options for Low-Income Countries' Effective and Efficient Use of Tax Incentives for Investment. Washington: International Monetary Fund.

Jacobs, P. 2014. BI Rate tetap 7,50\%: Bauran Kebijakan Bank Indonesia Diperkuat. Retrieved from Siaran Pers. http://www.bi.go.id/id/ruang-media/ siaran-pers/Pages/SP_160214.aspx

Kaplan, S.N. \& Zingales, L. 1997. Do Investment-Cash Flow Sensitivities Provide Useful Measures of Financing Constraints? Quarterly Journal of Economics, 112: 169-215.

Kaplan, S.N. \& Zingales, L. 2000. Investment-Cash Flow Sensitivities are not Valid Measures of Financing Constraints. The Quarterly Journal of Economics, 115(2): 707-712.

Khan, A.S. \& Adom, A.Y. 2015. A Test of the Pecking Order Theory of Capital Structure in Corporate Finance. Accounting $\mathcal{E}$ Taxation, 7(2): 43-49.

Lemmon, M.L. \& Zender, J.F. 2016. Asymmetric Information, Debt Capacity, and Capital Structure. Journal of Financial and Quantitive Analysis, 45(5): 11611187.

Media-Industri. 2013. Perkembangan Industri Manufaktur 2013. Media Industri, 05, 62.

Media-Industri. 2016. Industri Makanan \& Minuman Jadi Andalan. Media Industri, 2, 64. 
Moyen, N. 2004. Investment-Cash Flow Sensitivities: Constrained Versus Unconstrained Firms. The Journal of Finance, 59(5): 2061-2092.

Myers, S.C. \& Majluf, N.S. 1984. Corporate Financing and Investment Decisions When Firms Have Information that Investors Do Not Have. Journal of Financial Economics, 13(2): 187-221.
Vogt, S.C. 1994. The Cash Flow/ Investment Relationship: Evidence from U.S. Manufacturing Firm. Financial Management, 23(2): 3-20. 